\title{
CORRELATION BETWEEN ALLEN'S AND INVERSE ALLEN'S TESTS WITH DIAMETERS OF ULNAR AND RADIAL ARTERIES
}

\author{
${ }^{1}$ Alice I. Supit \\ ${ }^{2}$ Bambang Budiono \\ ${ }^{1}$ Reginald L. Lefrandt
}

${ }^{1}$ Department of Cardiology and Vascular Medicine Faculty of Medicine
University of Sam Ratulangi Manado
${ }^{2}$ Heart and Vascular Centre Awal Bros Hospital Makassar
Email: alicesupit@yahoo.co.id

\begin{abstract}
Abstrak: Arteri radialis semakin sering dipergunakan sebagai akses alternatif angiografi koroner dan intervensi karena dibanding akses femoralis, komplikasi perdarahan lebih rendah, mobilisasi lebih dini, dan biaya lebih murah. Terdapat beberapa hal yang dapat mengurangi keberhasilan prosedur ini; salah satunya ialah kegagalan pungsi karena ukuran a. radialis yang kecil. Studi sebelumnya menunjukkan bahwa uji Allen dapat digunakan untuk mendeteksi arteri dengan diameter yang lebih besar. Penelitian ini bertujuan untuk mengevaluasi apakah uji Allen dan inverse Allen berkorelasi dengan diameter a. ulnaris dan a. radialis. Penelitian ini berlangsung dari Juli hingga Desember 2012 di Laboratorium Kateterisasi Rumah Sakit Awal Bros Makassar. Pasien menjalani uji Allen dan inverse Allen sebelum prosedur. Ukuran diameter dalam dari lumen arteri radialis dan ulnaris diukur oleh operator dengan menggunakan analisis angiografi kuantitatif (operator tidak mengetahui hasil uji Allen). Uji Spearman's rho digunakan untuk menganalisis korelasi antara uji Allen dan inverse Allen dengan diameter a. radialis dan a. ulnaris dengan $P<0,05$ dianggap bermakna. Analisis statistik menggunakan SPSS versi 19. Hasil penelitian memperlihatkan 121 pasien (98 lakilaki dan 23 perempuan, rerata usia 57,5 (SD \pm 11,9 tahun). Frekuensi crossover 3,3\%. Uji Allen dan inverse Allen normal pada 116 pasien (95,8\%). Rerata diameter a. radialis dan ulnaris ialah 2,14 (SD $\pm 0,34 \mathrm{~mm})$ dan 1,95 (SD $\pm 0,45 \mathrm{~mm})$. Uji korelasi Spearman's rho menunjukkan korelasi bermakna antara uji Allen dan diameter a. ulnaris $(P=0,000 ; \mathrm{r}=$ $0,485)$; uji inverse Allen dan diameter a. radialis $(P=0,015 ; \mathrm{r}=-0,220)$. Simpulan: Terdapat korelasi bermakna antara uji Allen dengan diameter a. ulnaris, dan uji inverse Allen dengan diameter a. radialis. Kedua uji ini sederhana dan dapat memberikan informasi tentang arteri mana memiliki diameter yang lebih besar. Bila uji Allen normal, maka a.ulnaris dapat dipergunakan sebagai akses alternatif ketika akses radialis gagal atau bahkan sebagai akses inisial jika uji inverse Allen abnormal atau waktu uji Allen lebih singkat dari inverse Allen, terutama untuk prosedur intervensi yang memerlukan arteri yang lebih besar sebagai akses.
\end{abstract}

Kata kunci: uji Allen, uji inverse Allen, diameter, arteri radial, arteri ulnaris.

\footnotetext{
Abstract: Radial artery has been increasingly used as an alternative site for coronary angiography and intervention because of its advantages over femoral access, such as: a reduction in bleeding complications, early mobilisation, and lower cost. Despite these advantages, there are some challenges that reduce procedural success. One of them is the puncture failure owing to the small vessel size. A previous study has demonstrated consistently that the Allen test may be used for detecting the artery with the largest diameter. This study aimed to evaluate whether the Allen's and inverse Allen's tests correlate to the diameters of ulnar and radial arteries. This study was conducted from July to December 2012 in the Catheterization Laboratory of Awal Bros Hospital Makassar. Patients underwent the Allen's and inverse Allen's test before the procedure. The inner luminal diameters of radial
} 
and ulnar arteries were measured by an operator using quantitative angiographic analysis software. The operator was blinded to the results of the Allen's tests. The Pearson correlation test was used to analyze the correlation between Allen's and inverse Allen's test with the diameters of the radial and ulnar arteries. A $P$-value of $<0.05$ was considered as statistically significant. Statistical analysis was performed with Statistical Package for Social Sciences (SPSS) version 19. The results showed that there were 121 patients (98 males and 23 females, the mean age being 57.5 ( $\mathrm{SD} \pm 11.9$ years). The crossover rate was $3.3 \%$. Both of the Allen's and inverse Allen's tests were normal in 116 patients (95.8\%). By using a quantitative coronary analysis software, the mean diameters of the radial and the ulnar arteries were 2.14 ( $\mathrm{SD} \pm 0.34 \mathrm{~mm}$ ) and 1.95 (SD $\pm 0.45 \mathrm{~mm}$ ), respectively. The Spearman's rho correlation test showed significant correlations between the Allen's test and diameters of ulnar arteries $(P=$ $0.000 ; \mathrm{r}=-0.485)$, and between the inverse Allen's test and diameters of radial arteries $(P=$ $0.015 ; r=-0.220$ ). Conclusion: The Allen's test correlated to the diameters of the ulnar arteries and the inverse Allen's test correlated to the diameters of the radial arteries. The normal Allen's test indicated that the ulnar artery might be used as an alternative access site when the radial approach failed or even as an initial access if the inverse Allen's test was abnormal or the Allen's test was shorter than the inverse Allen's test, especially for the intervention procedure which needed a larger artery as the access site. These tests are simple and may provide some important information about arteries with larger diameters. Future studies with larger series of patients will be necessary to confirm our results.

Keywords: Allen's test, inverse Allen's test, diameter, radial artery, ulnar artery.

Coronary angiography (CA) and percutaneous coronary intervention (PCI) are important diagnostic and treatment tools for coronary artery diseases. The procedures can be performed via transradial, transulnar, transfemoral, or transbrachial access. ${ }^{1,2}$ Recently, the transradial access has become more popular. It has several advantages over the transfemoral approach such as a reduction in access site complications, early patient mobilization, relative lower cost of hospitalization, and increase in patient comfort. ${ }^{1,3,4}$ Despite these advantages, there are some challenges that reduce procedural success which leads to a crossover. One of them is the puncture failure owing to the small vessel size. ${ }^{1,3,5}$ The artery size is one of the pivotal factors that generally influences an operator's choice. Asian populations, especially Asian females tend to have small caliber radial arteries, which could make this route more challenging. ${ }^{7}$

The Allen's test is a widely used screening method to verify the presence of collateral blood supply and to exclude insufficient dual blood flow to the hand. ${ }^{1}$ However, as many as $23.4 \%$ interventional cardiologists do not perform it. ${ }^{8}$ The criteria for an abnormal Allen's test are not uniformly agreed upon. ${ }^{3}$ The Allen's test, albeit of being cheap and simple, has been criticized for being too subjective, and it gives no morphological information of the artery. ${ }^{9}$ A previous study of Gourassas et al. ${ }^{10}$ has demonstrated consistently that the Allen's test may be used for detection of the largest diameter artery.

In this study, on every patient, we performed angiography of the arm via the radial artery to measure the diameters of the radial and ulnar arteries by using a quantitative angiographic analysis. We aimed to evaluate whether the Allen's and inverse Allen's test correlated with the sizes of ulnar and radial arteries, respectively.

\section{METHODS}

This was a cross-sectional singlecenter study of patients who underwent transradial coronary angiography. This study was carried out from July to December 2012 in the Catheterization Laboratory of Awal Bros Hospital Makassar. 


\section{Study population}

All patients $(\mathrm{n}=121)$ undergoing transradial coronary angiographies, followed or not by coronary intervention during this study, were considered as the inclusion criteria. The exclusion criteria was patients with non-palpable radial pulses. All patients had to sign informed consents.

\section{Allen's and inverse Allen's test}

There were 121 patients who underwent the Allen's and inverse Allen's tests prior to the coronary angiography. All tests were performed by one physician in the catheterization laboratory. The operator was blinded to the results of tests.

The Allen's test was done to assess the ulnar patency. The inverse Allen's test referred to the same test by aiming at the radial artery patency. The tests were performed as follows: 1 ) The patient's right wrist should relax in a slightly flexed position, then the patient was asked to clench his/her fist; 2) There was simultaneous occlusion of the radial and ulnar arteries at the wrist until the hand blanched; 3) Pressure was released over the ulnar artery; 4) We observed the time for palmar skin to return to normal (maximal blush); 5) There was a simultaneous occlusion of the radial and ulnar artery at the wrist until the hand blanched. (6) The pressure was released over the radial artery; and (7) We observed the time for the palmar skin to return to normal (maximal blush) A cut-off of abnormal result was adopted from the Transradial Committee of the Society for Coronary Angiography and Interventions (SCAI) where reperfusion of the hand taking longer than 15 seconds was considered as abnormal.

\section{Arteriography of the arm}

Under local anesthesia, a sheath was inserted into the right radial artery. A 5 Fr (length $7 \mathrm{~cm}$, Merit Medical, US) sheath was utilized in patients who underwent transradial CA and a 6 Fr (length $7 \mathrm{~cm}$, Merit Medical, US) sheath in the transradial CA, followed by PCI. Heparin $5000 \mathrm{IU}$ and isosorbide dinitrate $300 \mathrm{ug}$ were mixed with normal saline $5 \mathrm{cc}$ in one syringe and injected into the radial artery. The arteriography of the arm was performed before a coronary angiography. A contrast of $4 \mathrm{ml}$ Lopamiro was injected from the inserted sheath to acquire the arm arteriography. The arteriography was performed on all the radial and ulnar arteries using an anteroposterior projection.

\section{Quantitative angiographic analysis}

Quantitative angiographic analysis was performed with an automated edge detection system (Quantitative coronary analysis, Xcelera R3.1L1 3.1.1.422 - 2009, Philips) by the operator. The outer luminal diameter of the inserted sheath was used as the calibration reference for the quantitative angiographic analysis. A zoom tool was used to magnify the measurement area. The inner luminal diameter of the radial artery was measured right after the sheath. The inner luminal diameter of the ulnar artery was measured parallel to the radial artery.

\section{Statistical analysis}

A Spearman's rho correlation test was used to analyze the correlation between the Allen's test and the ulnar artery diameter and the correlation between the inverse Allen's test and the radial artery diameter. A $P$-value $<0.05$ was considered as statistically significant. Statistical analysis was performed with the SPSS software version 19.

\section{RESULTS}

\section{Clinical and angiographic characteristics}

Among 121 patients, 98 (80.9\%) were male. The most common indication for coronary angiography was unstable angina pectoris (Table 1). Significant coronary stenosis was found in 82 patients (67.7\%). A three-vessel disease was found to be the most frequent (31\%) significant finding. The descriptive statistics of study 
population were shown in Table 2 and the procedural characteristics of coronary angiography were shown in Table 3.

The mean inner luminal diameter of the radial arteries was 2.14 ( $\mathrm{SD} \pm 0.34 \mathrm{~mm}$ ) and of the ulnar arteries 1.95 (SD \pm $0.45 \mathrm{~mm}$ ) (Table 2).

Table 1. Demographic and angiographic characteristics of study population
Table 3. Procedural characteristics of coronary angiography

\begin{tabular}{|c|c|c|}
\hline Variables & $\mathbf{n}$ & Mean \pm SD \\
\hline $\begin{array}{l}\text { Duration } \\
\text { (mins) }\end{array}$ & 121 & $\begin{array}{c}6.1 \pm 2.16 \\
(4.07-25.2)\end{array}$ \\
\hline $\begin{array}{l}\text { Contrast amount } \\
(\mathrm{mL})\end{array}$ & 121 & $\begin{array}{l}34.32 \pm 9.26 \\
\quad(26-60)\end{array}$ \\
\hline $\begin{array}{l}\text { Fluoroscopy } \\
\text { time (mins) }\end{array}$ & 121 & $\begin{array}{l}2.37 \pm 1.45 \\
(1.01-7.50)\end{array}$ \\
\hline $\begin{array}{l}\text { Fluoroscopy } \\
\text { dose (mGy) }\end{array}$ & 121 & $\begin{array}{c}423.087 \pm 165.64 \\
(128.101-1040.19)\end{array}$ \\
\hline
\end{tabular}

\begin{tabular}{lcc}
\hline \multicolumn{1}{c}{ Variables } & n & $\begin{array}{c}\text { Percentage } \\
\text { (\%) }\end{array}$ \\
\hline Male & 98 & 80.9 \\
Female & 23 & 19.1 \\
Hypertension & 69 & 57.0 \\
Diabetes mellitus & 24 & 19.8 \\
Dyslipidemia & 58 & 47.9 \\
Smoker & 45 & 37.2 \\
Previous PCI & 15 & 12.4 \\
Indication for CA & & \\
Unstable angina pectoris & 44 & 36.4 \\
Myocardial infarction & 18 & 14.9 \\
Stable angina pectoris & 31 & 25.6 \\
Left ventricular $\quad$ dys- & 15 & 12.4 \\
function & & \\
Positive stress test & 13 & 10.7 \\
\hline Results of CA & & \\
Significant CAD & 82 & 67.7 \\
Left main disease & 4 & 3.6 \\
3-vessel disease & 36 & 31 \\
2-vessel disease & 24 & 20.1 \\
1-vessel disease & 22 & 19.2 \\
Moderate CAD & 13 & 10.7 \\
Non-significant CAD & 16 & 13.7 \\
Normal coronary artery & 7 & 5.7 \\
LAD bridging & 7 & 6 \\
\hline
\end{tabular}

Table 2. Descriptive statistics of study population

\begin{tabular}{|c|c|c|}
\hline Variables & $\mathbf{n}$ & Mean \pm SD \\
\hline Age (years) & 121 & $\begin{array}{l}57.5 \pm 11.9 \\
(33-82)\end{array}$ \\
\hline Weight (kg) & 121 & $\begin{array}{c}67.73 \pm 14.02 \\
(45-95)\end{array}$ \\
\hline Height (cm) & 121 & $\begin{array}{c}164.75 \pm 34.1 \\
(155-185)\end{array}$ \\
\hline $\operatorname{BMI}\left(\mathrm{kg} / \mathrm{m}^{2}\right)$ & 121 & $25.27 \pm 4.23$ \\
\hline $\begin{array}{l}\text { Radial artery } \\
\text { diameter }(\mathrm{mm})\end{array}$ & 121 & $2.14 \pm 0.34$ \\
\hline $\begin{array}{l}\text { Ulnar artery } \\
\text { diameter }(\mathrm{mm})\end{array}$ & 121 & $1.95 \pm 0.45$ \\
\hline
\end{tabular}

The rate of the procedural success was 96.6\%. Crossover was done in 4 patients. Among those 4 patients, both Allen's and inverse Allen's tests were normal in 3 patients while in one patient, the inverse Allen's test was abnormal (Table 4).

Table 4. Crossover regarding the result of Allen's test

\begin{tabular}{|c|c|c|}
\hline & n (\%) & $\begin{array}{c}\text { Crossover } \\
\text { (\%) }\end{array}$ \\
\hline Normal & 116 (95.9) & $3(2.5)$ \\
\hline $\begin{array}{l}\text { Abnormal Allen's } \\
\text { test }\end{array}$ & 4 (3.3) & $1(0.8)$ \\
\hline $\begin{array}{l}\text { Abnormal inverse } \\
\text { Allen's test }\end{array}$ & $1(0.8)$ & 0 \\
\hline $\begin{array}{l}\text { Abnormal Allen's } \\
\text { and inverse Allen's } \\
\text { test }\end{array}$ & 0 & 0 \\
\hline Total & $121(100)$ & $4(3.3)$ \\
\hline
\end{tabular}

Correlation between Allen's and inverse Allen's test with diameters of ulnar and radial arteries

The Spearman's rho correlation test showed significant correlations between the Allen's test and the diameter of the ulnar artery ( $P=0.000 ; \mathrm{r}=-0.485)$, and the inverse Allen's test and the diameter of the radial artery $(P=0.015 ; r=-0.220)$. The negative value of $r$ means that the larger the diameter of the artery, the shorter the time for palmar skin returning to normal.

\section{DISCUSSION}

Radial artery has been increasingly 
used as an alternative site of access for coronary angiography and intervention. The transradial approach has several advantages over the transfemoral approach such as a reduction in access site complications, early patient mobilization, relative lower cost of hospitalization, and increase in patient comfort. Despite these advantages, there are some challenges that reduce procedural success which leads to a crossover. One of them is failure of cannulation owing to the small vessel size. The Asian population, especially Asian females tend to have small caliber radial arteries because of their small body habitus, which could make this route more challenging. ${ }^{1-3,5,7}$

The transradial approach failure occurs in 1-9\% of cases; the main causes are due to failed radial puncture, anatomical variations of the radial artery and small caliber vessels. ${ }^{1,5,7,9,11,12}$ The procedural success rate for coronary angiography was $96.6 \%$ in our study which closely matches 94-97\% success rates achieved in some other studies. ${ }^{1,8}$ There were 4 cases (3.3\%) of procedural failures in which crossovers were required. The reasons for the crossovers were puncture failures in 3 cases and the inability to insert the sheath in 1 case. One ulnar, two brachial, and one femoral artery were used as crossover sites. In one case with crossover to the ulnar artery, coronary angiography followed by intervention could be carried out without any ischemic complication after the procedure (Figure 1). In one patient with normal inverse Allen's test, angiography of the arm revealed no radial artery but a large interosseal artery which was used as the vascular access without any ischemic complication after the procedure (Figure 2).

Since no radial artery was shown in the arteriography, the pulsation might have originated from the interosseal artery, which explains why the inverse Allen's was normal in this patient.

The mean of radial and ulnar artery diameters in our study was 2.14 (SD \pm 0.34 $\mathrm{mm})$ and 1.95 (SD $\pm 0.45 \mathrm{~mm}$ ), respectively, which is close to the measure-

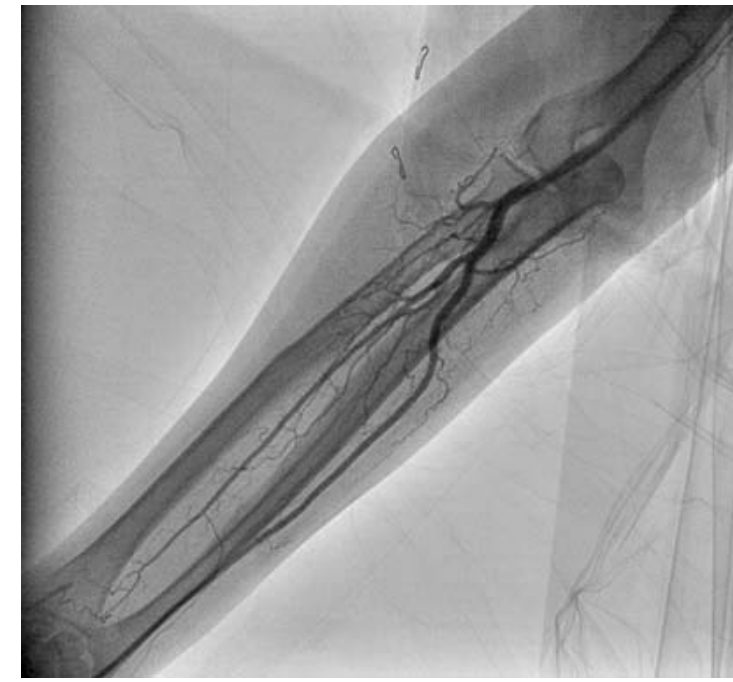

Figure 1. Arteriography showed a large ulnar artery, no radial artery, and only an interosseal artery. The PCI procedure was succesfully done through the ulnar artery. The patient had normal Allen's (2 seconds) and inverse Allen's test (5 seconds).

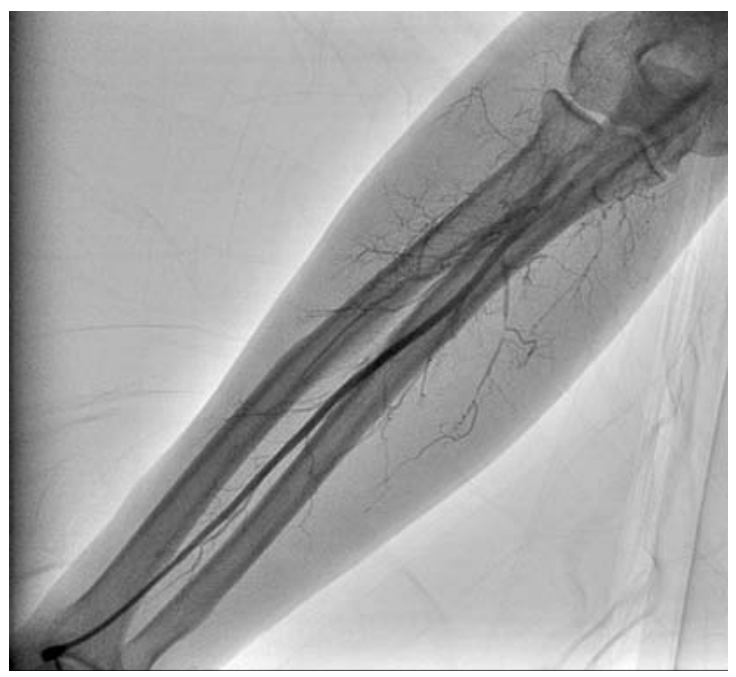

Figure 2. Angiography shows no radial and ulnar artery, and only a large interosseal artery. The patient had a normal inverse Allen's test (6 seconds) while the ulnar artery was not palpable. Coronary angiography and PCI could be carried out without ischemic complications after the procedure.

ment taken by Ashraf et $\mathrm{al}^{4}$ and Loh et al. ${ }^{11}$ In this study, the diameters of arteries were measured using the quantitative angiographic analysis. There was one previous study of Fuuji et al. ${ }^{14}$ that used the quantitative angiographic analysis to 
evaluate arm arteries, while other studies used the Doppler ultrasound. ${ }^{4,9,11,13}$ In our study, the diameters of arteries might be slightly larger than their actual sizes because the measurements of diameters were done at the points right after the sheaths, while in others using the Doppler ultrasound, most measurements were done at the puncture points $(2 \mathrm{~cm}$ proximal to the radial styloid). ${ }^{4,9,11,13}$ However, Fuuji et al. ${ }^{14}$ asserted that by using the quantitative angiographic analysis, diameters of the radial arteries which were measured within 10-60 $\mathrm{mm}$ above the radio-ulnar line, were nearly invariable throughout the range. ${ }^{14}$ Nasr et al. ${ }^{15}$ found the mean of radial artery diameter was $3.2(\mathrm{SD} \pm 0.66 \mathrm{~mm})$ at $1 \mathrm{~cm}$ distal to its origin and 3.0 (SD $\pm 0.66 \mathrm{~mm}$ ) at $2 \mathrm{~cm}$ proximal to the styloid process of the radius. ${ }^{15}$

The radial artery has a superficial course, and there are no nerves or veins of significant size near the usual site of puncture. The hand's dual arterial supply from the radial and the ulnar arteries adds an extra level of safety to the arterial puncture. Before attempting the transradial access, it is important to ascertain that the Allen's test is normal, thus confirming an adequate collateral arterial supply from the ulnar artery. In a study by Benit et al. ${ }^{12}$ on 1,000 patients undergoing cardiac catheterization, $83 \%$ had a normal Allen's test. In our study, $96.6 \%$ of patients had normal Allen's and inverse Allen's tests. The cutoff used in this study was adopted from Core Curriculum by Transradial Commitee of SCAI, with reperfusion of more than 15 seconds being considered as abnormal. ${ }^{1}$ The frequency of normal Allen's and inverse Allen's tests was higher in our study compared to previous studies. This was probably due to the un-uniform execution of an Allen's test. In addition, while doing the test, a patient's hand was forced by the examiner's hand into a slightly flexed position, and this was not be hyperextended or hyperflexed, which might prolong the blanching period, resulting in false interpretation of the test.

Albeit being simple and cheap, there has been a debate whether the Allen's test is a sufficient screening method to exclude patients with possibly compromised hand circulation. The criteria for an abnormal Allen's test are not uniformly agreed upon. ${ }^{3}$ As many as $23.4 \%$ interventional cardiologists do not perform it. False normal rates range from $3 \%$ to $45.5 \%$, and false abnormal results were as high as $73 \%$, depending on the technique. ${ }^{8}$ Kohonen et al. found that Allen's test is a good and valid screening test to determine the circulation of the hand. ${ }^{9}$ Several authors have explored the question as to whether there might be a bedside clinical tool that could predict radial artery size without ultrasound imaging. ${ }^{16,17}$ Agrifolio et al. ${ }^{18}$ asserted that the Allen's test gave no morphological information of the artery. The less appreciated concept is the use of the Allen's test for radial artery size assessment. However, a previous study by Gourassas et al. ${ }^{10}$ has demonstrated consistently that the Allen's test may be used for detecting the artery with the largest diameter. Greenwood et al. ${ }^{19}$ also found that a longer Allen's test time was associated with larger radial and smaller ulnar artery sizes.

In this study, we found that the Allen's test was negatively correlated with the diameter of the ulnar artery and the inverse Allen's test was negatively correlated with the diameter of the radial artery. The finding of our study indicates that the Allen's and the inverse Allen's test may predict an artery with a larger diameter; the shorter the time it takes to a maximal blush, the larger the diameter of the artery. A normal Allen's test indicates that the ulnar artery may be used as an alternative access site when the radial approach fails or even as an initial access if the inverse Allen's test is abnormal or the Allen's test is shorter than the inverse Allen's, especially in a complex case or intervention procedure which may need a larger guiding catheter.

\section{CONCLUSION}

The Allen's test correlates with the 
diameter of the ulnar artery and the inverse Allen's test correlates with the diameter of the radial artery. These tests are simple and may provide some important information about arteries with larger diameters. A normal Allen's test indicates that the ulnar artery may be used as an alternative access site when the radial approach fails or even as an initial access if the inverse Allen's test was abnormal or the Allen's test is shorter than the inverse Allen's, especially in a complex case or intervention procedure which needs a larger guiding catheter. Future research with a larger series of patients will be necessary to confirm our results.

\section{ACKNOWLEDGEMENT}

We would like to thank the director of Awal Bros Hospital Makasssar who permitted us to carry out our study in this hospital.

Presented as a Young Investigator Award at the 22nd Annual Scientific Meeting of Indonesian Heart Association (Asmiha), Jakarta, Indonesia, April 5-7, 2013.

\section{REFERENCES}

1. Caputo R, Tremmel JA, Rao S, Gilchrist CI, Pyne C, Pancholy S, et al. Transradial arterial access for coronary and peripheral procedures: Executive summary by the Transradial Committee of the SCAI. Catheter Cardiovasc Interv [serial online]. 2011 [cited 2012 Dec 29];78(6):823-39. Available from: URL: http://www.scai.org/asset.axd?id =e627adf5-89b4-4e5a-a0229329db5c49fe\&t=63456959107573000 0. doi: $10.1002 / \mathrm{ccd} .23052$.

2. Caluk J. Procedural techniques of coronary angiography. In: Kirac S, editor. Advances in the Diagnosis of Coronary Atherosclerosis [monograph online]. Croatia, New York, Shanghai: Intech Publication, 2011; p.95-120. [cited 2012 Dec 29]. Available from: URL : http://www.intechopen.com/books/adva nces-in-the-diagnosis-of-coronary- atherosclerosis/procedural-techniquesof-coronary-angiography. doi: $10.5772 / 18612$

3. Ludwig J, Achenbach S, Daniel WG, Arnold M. The transradial approach. Herz. 2011;36:386-95.

4. Ashraf T, Panhwar Z, Habib S, Memon MA, Shamsi F, Arif J. Size of radial and ulnar artery in local population. $\mathrm{J}$ Pak Med Assoc. 2010;60(10):817-9.

5. Franchi E, Marino P, Biondi-Zoccai GG, De Luca G, Vassanelli C, Agostoni P. Transradial versus transfemoral approach for percutaneous coronary procedures. Current Cardiology Reports. 2009;11:391-7.

6. Freixa $X$, Trilla M, Feldman M, Jiménez M, Betriu A, Masotti M. Right versus left transradial approach for coronary catheterization in octogenarian patients. Catheterization and Cardiovascular Interventions. 2012;80:267-72.

7. Ali J, Aziz S, Javed A, Kayani AM. Transradial access for coronary angiography: A single operator's experience of 500 cases. Pak Arm Force Med J. 2010;12(10).

8. Bertrand OF, Rao SV, Pancholy S, Jolly SS, Rodés-Cabau J, Larose E. Transradial approach for coronary angiography and interventions. JACC: Cardiovascular Interventions 2010; 10(3):1022-31.

9. Kohonen M, Teerenhovi O, Terho T, Laurikka J, Tarkka M. Is the Allen test reliable enough? European Journal of Cardio-thoracic Surgery. 2007;32:902-5.

10. Gourassas J, Papadopoulos CE, Albedd U, Karoulas T, Billi A, Louridas G. The Allen and inverse Allen test, as a simple method for detecting ulnar or radial predominance. Sensitive but not specific. Eur Heart J. 2002; (Suppl)23:95.

11. Loh YJ, Naka M, Tan WD, Lin CH, Tan YS, Chua YL. Factors influencing radial artery size. Asian Cardiovasc Thorac Ann. 2007;15:324-6.

12. Benit E, Vranckx P, Jaspers L, Jackmaert R, Poelmans C, Coninx R. Frequency of a positive modified Allen $\mathrm{s}$ test in 1000 consecutive patients undergoing cardiac catheterization. Cathet Cardiovasc Diagn. 1996;38:352-4. 
13. Chugh SK, Chugh S, Rao SV. Feasibility and Utility of Pre-procedure Ultrasound Imaging of the Arm to facilitate TransRadial Coronary Diagnostic and Interventional Procedures. (PRIMA FACIE-TRI). Catheter Cardiovasc Interv. 2013; 82(1):64-73.

14. Fuuji T, Masuda N, Toda E, Shima M, Tamiya S, Ito D, et al. Analysis of right radial artery for transradial catheterization by quantitative angiography-anatomical consideration of optimal radial puncture point. J invasive cardiol. 2010;22(8):372-6.

15. Nasr AY. The radial artery and its variations: anatomical study and clinical implications. Folia Morphol (Warsz). 2012;71(4):252-62.

16. Yoo BS, Yoon J, Ko JY, Kim JY, Lee SH, Hwang S. Anatomical consideration of the radial artery for transradial procedures: arterial dia- meter, branching anomaly and vessel tortuosity. Int J Cardiol. 2005;101:421-7.

17. Saito S, Ikei H, Hosokawa G, Tanaka S. Influence of the ratio between radial inner diameter and sheath outer diameter on radial artery flow after transradial coronary intervention. Catheter Cardiovasc Interv. 1999; 46:173-8.

18. Agrifolio M, Barili F, Dainese L, Biglioli P. The Allen test is not adequate enough for the screening of hand circulation. Eur J Cardiothorac Surg. 2008;33:754.

19. Greenwood MJ, Della-Siega AJ, Fretz EB, Kinloch D, Klinke P. Vascular communication of the hand in patients being considered for transradial coronary angiography: is the Allen's test accurate? J Am Coll Cardiol. 2005;46:2013-7. 